
A
$\mathbf{R}$
$\mathbf{T}$
Y
$\mathbf{K}$
$\mathbf{U}$

\section{Struktura funkcjonalna i powiązania miast konurbacji katowickiej po dwu dekadach restrukturyzacji}

\author{
Functional structure and linkages between the towns \\ and cities of the Katowice conurbation \\ after two decades of post-socialist transition
}

\begin{abstract}
KRZYSZTOF GWOSDZ
Instytut Geografii i Gospodarki Przestrzennej, Uniwersytet Jagielloński, 30-387 Kraków, ul. Gronostajowa 7; krzysztof.gwosdz@uj.edu.pl
\end{abstract}

\title{
AGNIESZKA SOBALA-GWOSDZ
}

Instytut Inżynierii Technicznej, Państwowa Wyższa Szkoła Techniczno-Ekonomiczna w Jarosławiu, 37-500 Jarosław, ul. Czarnieckiego 16; asobala@poczta.fm

Zarys treści. Celem autorów jest określenie współczesnej struktury funkcjonalno-przestrzennej konurbacji katowickiej. Stwierdzono, że obecnie ma ona charakter raczej późnoindustrialny niż postindustrialny. Wskazano na dwa główne procesy wpływające na współczesne zorganizowanie funkcjonalno-przestrzenne konurbacji katowickiej: postępującą koncentrację usług ponadlokalnych w Katowicach oraz terytorialnie zróżnicowane procesy deindustrializacji i reindustrializacji.

Słowa kluczowe: konurbacja katowicka, aglomeracja policentryczna, restrukturyzacja regionów tradycyjnego przemysłu, ewolucja systemu miejskiego.

\section{Wstęp}

Transformacja gospodarcza zapoczątkowana w 1989 r., będąca z jednej strony przejściem od socjalizmu państwowego do gospodarki rynkowej i demokracji, a z drugiej elementem globalnej transformacji przełomu XX i XXI stulecia, była punktem zwrotnym ${ }^{1}$ w rozwoju konurbacji katowickiej - unikalnej w Polsce for-

\footnotetext{
${ }^{1}$ Punkt zwrotny definiujemy za A. Kuklińskim (2008, s. 5) jako głęboką i szybką transformację struktur i sił napędowych procesów rozwojowych.
} 
my osadniczej, która powstała w wyniku procesów XIX- i XX-wiecznej industrializacji opartej na energii pierwotnej pozyskiwanej ze złóż węgla kamiennego.

Współczesne funkcjonalno-przestrzenne zorganizowanie konurbacji katowickiej, mimo pojawienia się w ostatnim czasie wielu interesujących prac dotyczących problemów jej restrukturyzacji gospodarczej i przestrzennej (m.in. Klasik, 2008; Klasik i Kuźnik, 2008; Mikołajec, 2008; Tkocz, 2009; Krzysztofik i inni, 2011; Krzysztofik i Runge, 2011; Szczepański i inni, 2011), wciąż jest niezadowalająco poznane. Wiąże się to z brakiem zarówno adekwatnego modelu teoretycznego (zob. Runge, 2007, 2009), jak i szczegółowych i pełnych danych statystycznych dotyczących aktualnej struktury gospodarczej oraz powiązań i przepływów w sieci osadniczej. Toteż większość najnowszych prac sprowadza się głównie do analiz strukturalnych. Model przemian urbanizacyjnych, demograficznych i społecznych przedstawił ostatnio J. Runge (2011), próby uogólnień podjęli ponadto J. Runge i I. Żurek (2010) oraz J. Runge i inni (2011). Bardzo wartościowym kompendium wiedzy o przemianach historycznych obszaru konurbacji katowickiej są opracowania T. Spórny (2012) oraz R. Duliasa i A. Hibszera (2008).

Celem autorów niniejszej pracy jest określenie współczesnej struktury funkcjonalno-przestrzennej konurbacji katowickiej, a tym samym wniesienie wkładu do dyskusji nad funkcjonowaniem i trendami rozwojowymi tego złożonego systemu osadniczego. Artykuł zawiera odpowiedzi na trzy główne pytania:

1. Jak przedstawia się struktura funkcjonalna i hierarchia miast konurbacji katowickiej po dwóch dekadach restrukturyzacji (1989-2009)?

2. Jak kształtują się powiązania między poszczególnymi miastami konurbacji katowickiej (na przykładzie dojazdów do pracy w 2006 r.)?

3. Jak zaobserwowane prawidłowości wpisują się w teoretyczne ujęcia rozwoju systemów miejskich?

Zasięg konurbacji katowickiej przyjęto za R. Krzysztofikiem i J. Rungem (2011). Według tych autorów obejmuje ona 3,8 tys. $\mathrm{km}^{2}$ powierzchni, na której mieszka 2,7 mln osób w 57 gminach. 17 miast tworzy rdzeń metropolitalny (2,1 mln mieszkańców). Od czerwca 2007 r. 14 miast rdzenia konurbacji na prawach powiatu wchodzi w skład dobrowolnego związku międzygminnego (Górnośląski Związek Metropolitalny) ${ }^{2}$.

\section{Podstawy teoretyczne i metody badań}

Podstawą teoretyczną przyjętą w niniejszej analizie jest teoria systemu miejskiego, rozumianego jako „zintegrowany i zorganizowany zespół jednostek osadniczych, wzajemnie na siebie oddziałujących poprzez różnorodne powiązania i relacje" (Dziewoński i Jerczyński, 1978, s. 201).

\footnotetext{
${ }^{2}$ W stosunku do delimitacji R. Krzysztofika i J. Runge (2011) dokonano niewielkiej zmiany, wyłączając z jej obszaru miasta Chrzanów i Libiąż. W świetle dojazdów do pracy miasta te są silniej powiązane z Krakowskim Obszarem Metropolitalnym.
} 
Modelowe ujęcia wewnętrznej struktury powiązań systemu miejskiego przedstawił H. Blotevogel (1983). Gdyby wszystkich miast w danym systemie dotyczył podobny zestaw działalności (funkcji), to powiązania między nimi byłyby ograniczone lub nie istniałyby (ryc. 1A). Fakt ten potwierdzają niektóre badania dotyczące powiązań w obszarach o podobnej strukturze społeczno-ekonomicznej (Schöller i inni, 1984). W analizie porównawczej policentrycznych regionów miejskich Europy Zachodniej E. Meijers (2007) nazywa takie miasta „klonami” (clones). Ten specyficzny model systemu bez powiązań może dobrze opisywać szczególną fazę rozwoju układów policentrycznych, które powstały na bazie funkcji wyspecjalizowanej, np. górniczej. Tak długo, jak każde z sąsiadujących miast ma bazę ekonomiczną opartą na rozproszonych i zewnętrznych rynkach zbytu, jest ono relatywnie niezależne od swoich sąsiadów, zwłaszcza jeśli wytworzy przynajmniej podstawowy zestaw funkcji usługowych.

Drugim typem idealnym jest skrajna dywersyfikacja funkcjonalna, gdzie każdy element w systemie pełni inną funkcję (ryc. 1B). Istnieją wówczas warunki umożliwiające silną komplementarność poszczególnych miast. Takie relacje uzupełniające się są typowe dla „modelu sieciowego” miast, którego cechą jest - jak pisze E. Meijers (2007) - nakładanie się zaplecza poszczególnych miast, owocujące „neutralnością wielkościową” (size neutrality), tzn. relatywną niezależnością funkcji miasta od jego wielkości. W rezultacie powiązań komplementarnych miasto może mieć „wielkość zapożyczoną”, korzystając z rynku zbytu w innych miastach należących do sieci (zob. Alonso, 1973). Występowanie policentrycznych regionów miejskich o powiązaniach sieciowych jest jedną z cech postindustrialnej fazy rozwoju miast i aglomeracji, ostatnio szeroko dyskutowanej w zagranicznej oraz polskiej literaturze (m.in. Zborowski, 2005; Korcelli, 2011).

W trzecim modelowym ujęciu wiodący ośrodek systemu gromadzi wszystkie funkcje, podczas gdy inne miasta mają ich mniejszy zestaw (ryc. 1C). Powstają wówczas powiązania o charakterze podporządkowania. Taki sposób zorganizowania systemu miejskiego ma charakter hierarchiczny i jest dobrze opisany przez teorię ośrodków centralnych. W analizach układów wielkomiejskich taki układ nazywany jest hierarchiczno-funkcjonalnym, z nierównoprawnymi powiązaniami między centrum a peryferiami aglomeracji (Zborowski, 2005).

System miejski jest przykładem systemu dynamicznego, który zmienia swe właściwości pod wpływem nowych bodźców. Ewolucja ta zachodzi w wyniku ścierania się korzyści i niekorzyści aglomeracji, co powiązane jest z ogólniejszymi procesami rozwoju w zakresie krajowego i międzynarodowego podziału pracy i nowych możliwości komunikacji. N. Phelps i T. Ozawa (2003) wyróżniają cztery podstawowe etapy i formy aglomeracji w czasie jej rozwoju: przedprzemysłową, przemysłową, późnoprzemysłową i postindustrialną. Zwracają oni uwagę na kontrasty między poszczególnymi etapami, m.in. w charakterze korzyści zewnętrznych, struktury sektorowej działalności gospodarczych, źródeł 


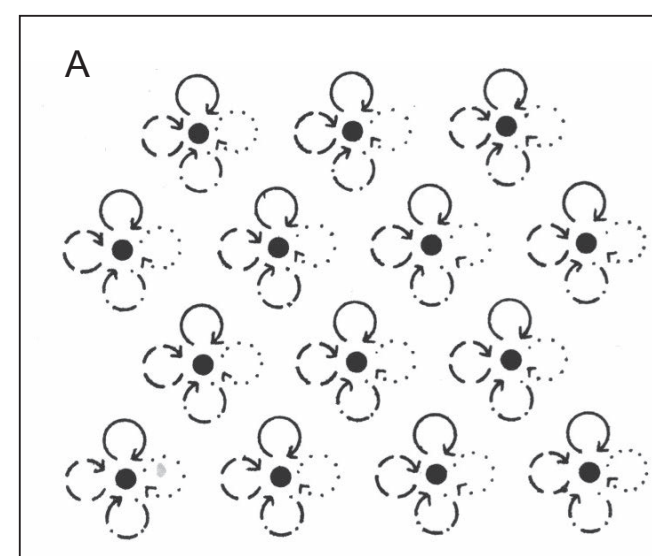

Brak specjalizacji funkcjonalnej Lack of functional specialization

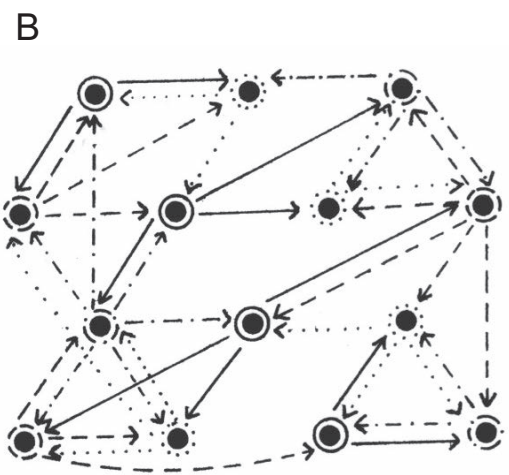

Komplementarność funkcjonalna Complementary specialization

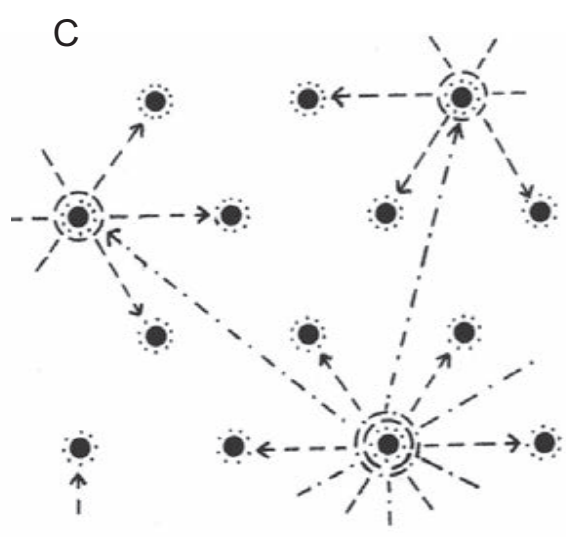

Hierarchia funkcjonalna Hierarchical specialization

Ryc. 1. Modelowe formy powiązań w systemie miejskim Basic forms of linkages in urban systems Źródło / Source: Blotevogel (1983). 
akumulacji kapitału oraz skali przestrzennej w jakiej wyrażają się siły aglomeracji, podkreślając konieczność wykazania przez badaczy wrażliwości na kontekst geograficzny i historyczny w analizie form zaglomerowanych. Na konieczność uwzględnienia aspektu genetycznego w analizie układów policentrycznych zwracają także uwagę S. Liszewski i W. Maik (2000), wskazując na odmienne „drogi dojścia” do współczesnej fazy organizacji przestrzenno-funkcjonalnej (obszar metropolitalny, miasto-region) układów o genezie policentrycznej (konurbacje) i monocentrycznej (aglomeracje). O ile bowiem aglomeracja miejska powstaje w wyniku działania sił dośrodkowych, dynamizujących pole oddziaływań każdego z miast rdzeniowych, o tyle konurbacje miejskie powstają w większości przypadków w efekcie działania sił odśrodkowych (Krzysztofik i Runge, 2011).

Niewątpliwie istnieje związek między pełnionymi przez dane miasto (aglomerację miejską) funkcjami a jego pozycją w sieci powiązań w systemie osadniczym. Ważna w tym względzie jest relacja zwrotna - aktualna pozycja miasta w sieci może istotnie wpływać na kierunek rozwoju miasta w przyszłości. Inspirująca jest pod tym względem zaproponowana przez M. Grochowskiego (2011) typologia relacji między układami osadniczymi na przykładzie metropolii. Autor ten wyróżnia: (1) relacje wyłączenia, kiedy dana metropolia jest izolowana w sieci powiązań, co prowadzi do jej dalszej marginalizacji; (2) relacje komplementarne i pomocnicze, które wzmacniają wszystkie uczestniczące w niej metropolie, a ponadto (3) relacje hierarchiczne o charakterze zrównoważonym oraz (4) relacje hierarchiczne o charakterze dominacji-zależności. Te ostatnie zachodzą $\mathrm{w}$ przypadku monopolizacji powiązań przez metropolię dominującą i mogą powodować „funkcjonalną peryferyzację” ośrodków podporządkowanych.

Aby określić funkcje, pozycję w hierarchii osadniczej oraz wzajemne powiązania miast konurbacji katowickiej zastosowano następującą procedurę badawczą: wykorzystując dane zakupione od Głównego Urzędu Statystycznego skonstruowano bazę pracujących według sekcji PKD w miastach konurbacji katowickiej w 2004 i 2008 r. Ponieważ GUS zbiera dane dotyczące liczby pracujących jedynie dla podmiotów o liczbie pracujących 10 i więcej osób, konieczne było oszacowanie całkowitej liczby pracujących w miastach konurbacji przy uwzględnieniu zatrudnienia w tzw. mikrofirmach (z liczbą pracujących osób mniejszą niż 10). W tym celu zakupiono od GUS bazę REGON zawierającą dane o liczbie aktywnych mikrofirm według sekcji PKD. Następnie, opierając się na badaniach reprezentacyjnych GUS (Działalność gospodarcza..., 2009), które pozwalają na oszacowanie całkowitej liczby pracujących w mikrofirmach według sekcji PKD na poziomie województwa, obliczono średnią liczbę pracujących przypadającą na 1 podmiot $\mathrm{w}$ danej sekcji PKD. Jako że zastosowano mnożniki oparte na 
szacunkach GUS, całkowita liczba osób pracujących w przemyśle nie odbiega od danych na poziomie województw podawanych w publikacjach GUS ${ }^{3}$.

Skonstruowana baza danych była podstawą obliczenia podstawowych charakterystyk bazy ekonomicznej, takich jak jej wielkość i poziom zróżnicowania. Posłużono się klasyczną metodą szacowania wielkości sektora egzogenicznego na podstawie tzw. nadwyżki pracowników, przy czym jako wielkość normalizującą - podobnie jak w pracy D. Sokołowskiego (2008) - przyjęto liczbę mieszkańców danego miasta i kraju. Obliczono w ten sposób wielkość bazy ekonomicznej (nadwyżkę pracujących) dla każdego miasta w rozbiciu na sekcje PKD, co było podstawą do określenia specjalizacji funkcjonalnej miast.

Kolejnym etapem było wyznaczenie rangi ośrodków pod względem funkcji centralnych, przeprowadzone dwiema komplementarnymi metodami: (1) skalarnego wskaźnika syntetycznego (Działek i inni, 2010) obliczonego na podstawie liczby instytucji i placówek usługowych (60 różnych typów podmiotów) oraz (2) wielkości sektora egzogenicznego w działalnościach usługowych (sekcje G-Q PKD 2004), przyjmując za H. Blotevogelem (1983), że nadwyżka pracujących $\mathrm{w}$ usługach oddaje $\mathrm{w}$ przybliżeniu pełnione przez dane miasto funkcje centralne.

Określenie specjalizacji funkcjonalnej i hierarchii miast pozwala wnioskować o „potencjalnej” komplementarności gospodarki różnych miast. Jak jednak wskazuje P. Korcelli (2011), komplementarność i bliskość geograficzna nie jest wystarczającym warunkiem istnienia powiązań funkcjonalnych, nawet jeśli spełnione są pozostałe warunki „triady Ullmana”, tj. brak możliwości pośrednich i przenośności. Specjalizacja funkcjonalna może bowiem dotyczyć różnych poziomów systemów miejskich (Korcelli, 2011). Konieczne jest wobec tego zbadanie faktycznych powiązań funkcjonalnych. Te określono na podstawie liczby i kierunków dojazdów do pracy w 2006 r., opierając się na udostępnionych przez GUS danych z bazy POLTAX (Kruszka, 2010).

\section{Potencjał gospodarczy miast konurbacji katowickiej i ich specjalizacja funkcjonalna}

Na terenie konurbacji katowickiej - w przeciwieństwie do podobnych genetyczno-funkcjonalnie struktur Europy Zachodniej (np. Zagłębie Ruhry), gdzie procesy przekształceń monofunkcyjnego kompleksu górniczo-hutniczego wyraźnie zaznaczyły się już w latach 1950. - mieliśmy do czynienia z zakonserwowaniem w okresie PRL-u zastanej struktury gospodarczej (Klasik, 1987;

\footnotetext{
3 Trzeba podkreślić, że obliczony wskaźnik średniej liczby pracujących na 1 mikrofirmę ma jedynie charakter mnożnika, tzn. służy do oszacowania liczby pracujących w mikrofirmach w danym mieście, a nie określenia rzeczywistej średniej liczby osób pracujących w 1 mikrofirmie. Wiąże się to z faktem, że w bazie REGON znajduje się wiele nieaktywnych podmiotów, a weryfikacja stopnia nadreprezentatywności tego rejestru jest odrębnym, dużym przedsięwzięciem badawczym.
} 
Kłosowski i inni, 1996). Wszystkie średnie i duże miasta konurbacji w końcu lat 1980., poza kilkoma jej peryferyjnymi ośrodkami, były wyspecjalizowanymi miastami przemysłowymi, przy czym ich zdecydowana większość miała charakter monostruktury górniczej, górniczo-hutniczej lub hutniczo-górniczej. W 1989 r. w przemyśle pracowało niespełna 600 tys. osób (64\% pracujących ogółem), w tym ponad 340 tys. w kopalniach węgla kamiennego, a blisko 100 tys. w hutnictwie żelaza i metali kolorowych (tab. 1). Wyraźny był niedobór działalności usługowych. Wśród większych miast funkcja usługowa odgrywała dominującą rolę jedynie w Katowicach (63\% zatrudnionych) i Mikołowie (65\%). Ośrodkiem koncentracji usług o znaczeniu ponadregionalnym były ponadto Gliwice, a pojedyncze usługowe funkcje regionalne pełniło kilka innych miast rdzenia (Sosnowiec, Bytom, Chorzów, Zabrze).

Dwie dekady 1990-2010 przyniosły głęboką zmianę regionalnego rynku pracy. Liczba pracujących w tradycyjnych sektorach przemysłowych - górnictwie, hutnictwie i energetyce - zmniejszyła się o około 300 tys., wzrosła natomiast rola innych branż przemysłu przetwórczego, a przede wszystkim usług. W $2008 \mathrm{r}$. udział trzeciego sektora wynosił 62\%, czyli o 26 punktów procentowych więcej niż w 1987 r., podczas gdy udział górnictwa, hutnictwa i energetyki nie przekraczał 12\% (w 1987 r. około 40\%).

Jednym z głównych problemów konurbacji katowickiej jest silne zróżnicowanie procesów rozwoju gospodarczego poszczególnych miast po $1990 \mathrm{r}$. (Domański, 2003; Gwosdz, 2004). Nasycenie miejscami pracy poszczególnych miast konurbacji katowickiej jest współcześnie mocno zróżnicowane (ryc. 2). Grupa miast o dużej liczbie miejsc pracy obejmuje dwa główne typy ośrodków: wyspecjalizowane miasta przemysłowe - górnicze (Bieruń, Lędziny, Knurów), bądź przemysłu przetwórczego (Tychy, Siewierz) - oraz polifunkcyjne ośrodki rdzenia (Katowice, Gliwice) i strefy peryferyjnej (Tarnowskie Góry, Mikołów). Wśród dziesięciu miast z relatywnie niską liczbą pracujących per capita, siedem - to ośrodki miejskie rdzenia, które utraciły po 1990 r. dużą liczbę miejsc pracy w tradycyjnych gałęziach przemysłu: Zabrze, Jaworzno, Piekary Śląskie, Siemianowice, Bytom, Czeladź i Świętochłowice.

Analiza nasycenia miejscami pracy (ryc. 2) oraz sektorowej struktury pracujących (ryc. 3) ujawnia dwie istotne prawidłowości. Pierwszą jest silna dezindustrializacja centralnej i północnej części rdzenia konurbacji, czyli ośrodków, które kiedyś tworzyły jądro przemysłowe tego regionu. Dotyczy to przede wszystkim takich miast jak Bytom, Chorzów, Zabrze, Siemianowice Śl., Świętochłowice i Sosnowiec. W żadnym z nich liczba pracujących w przemyśle nie sięga 3/4 średniej dla całej konurbacji. Druga prawidłowość - to wzrost znaczenia południowej części konurbacji oraz jej strefy zewnętrznej. Wynika to po pierwsze z faktu, że recesja branż tradycyjnych, zwłaszcza górnictwa, miała miejsce głównie w strefie północnej i wschodniej, po drugie zaś - z szybszego powstawania nowych miejsc pracy w części południowej i na obrzeżu rdzenia, które to 
Tabela 1. Pracujący według sekcji PKD 2004 w miastach rdzenia konurbacji katowickiej w 2008 r.

Workplaces in the core towns of Katowice Conurbation by NACE rev.1.1.

\begin{tabular}{|c|c|c|c|c|c|c|c|c|c|c|c|c|c|c|}
\hline \multirow{2}{*}{$\begin{array}{c}\text { Miasto } \\
\text { Town }\end{array}$} & \multirow{2}{*}{$\begin{array}{l}\text { Pracujący }^{\mathrm{a}} \\
\text { Employed } \\
\text { persons }^{\mathrm{a}}\end{array}$} & \multicolumn{13}{|c|}{ Pracujący według sekcji PKD 2004 / Employed persons by NACE rev.1.1. sections } \\
\hline & & $\mathrm{A}+\mathrm{B}$ & $\mathrm{C}+\mathrm{E}$ & $\mathrm{D}$ & $\mathrm{F}$ & G & $\mathrm{H}$ & I & $\mathrm{J}$ & K & $\mathrm{L}$ & M & $\mathrm{N}$ & $\mathrm{O}+\mathrm{P}+\mathrm{Q}$ \\
\hline Katowice & 192090 & 568 & 17243 & 21012 & 13388 & 34398 & 4091 & 16279 & 9290 & 29652 & 10819 & 14142 & 13256 & 7952 \\
\hline Gliwice & 89932 & 461 & 4667 & 24642 & 5793 & 13536 & 1906 & 6764 & 1677 & 14488 & 3023 & 7206 & 3580 & 2190 \\
\hline Sosnowiec & 74094 & 355 & 2465 & 16667 & 4456 & 17016 & 1604 & 5122 & 1413 & 8990 & 2535 & 5891 & 5437 & 2144 \\
\hline Tychy & 59402 & 150 & 925 & 24906 & 3685 & 9811 & 1003 & 3081 & 1586 & 5909 & 1333 & 2891 & 2658 & 1466 \\
\hline Zabrze & 54709 & 83 & 5462 & 8451 & 5467 & 10242 & 845 & 3191 & 1095 & 6018 & 2324 & 4592 & 4599 & 2339 \\
\hline Dąbrowa Górnicza & 51062 & 159 & 1506 & 18988 & 3419 & 8393 & 996 & 4043 & 793 & 4890 & 1156 & 3197 & 2054 & 1468 \\
\hline Bytom & 47102 & 207 & 5233 & 5745 & 3541 & 9509 & 1196 & 2503 & 1032 & 5273 & 1746 & 4532 & 4286 & 2298 \\
\hline Ruda Śląska & 45156 & 142 & 13980 & 5414 & 2184 & 8175 & 633 & 1888 & 725 & 2795 & 1266 & 3297 & 2678 & 1980 \\
\hline Chorzów & 36947 & 108 & 880 & 7695 & 2845 & 7798 & 906 & 2601 & 737 & 3927 & 2121 & 2741 & 2537 & 2051 \\
\hline Jaworzno & 27385 & 81 & 5257 & 4106 & 1551 & 4436 & 583 & 2717 & 541 & 2064 & 996 & 2227 & 1694 & 1132 \\
\hline Mysłowice & 26657 & 85 & 6231 & 4059 & 1598 & 5210 & 424 & 1389 & 414 & 2393 & 839 & 2061 & 1125 & 828 \\
\hline Tarnowskie Góry & 23973 & 125 & 429 & 5966 & 1261 & 4693 & 571 & 2518 & 379 & 1775 & 1494 & 1669 & 2255 & 840 \\
\hline Będzin & 19589 & 71 & 1981 & 2622 & 1976 & 4073 & 310 & 1438 & 385 & 1953 & 927 & 1277 & 1564 & 1013 \\
\hline Siemianowice Śląskie & 18715 & 49 & 159 & 5742 & 1755 & 3604 & 372 & 902 & 480 & 1695 & 654 & 1428 & 1150 & 725 \\
\hline Piekary Śląskie & 15667 & 42 & 4144 & 2154 & 705 & 2823 & 274 & 585 & 255 & 1034 & 397 & 1096 & 1351 & 806 \\
\hline Świętochłowice & 12222 & 66 & 169 & 2720 & 1161 & 2635 & 241 & 1503 & 192 & 853 & 276 & 946 & 854 & 607 \\
\hline Czeladź & 8302 & 34 & 290 & 1285 & 592 & 2988 & 273 & 550 & 155 & 663 & 145 & 651 & 353 & 323 \\
\hline
\end{tabular}

${ }^{a}$ wliczając pracujących w mikrofirmach. / including workplaces in microcompanies (below 10 employees).

Obliczenia własne na podstawie niepublikowanych danych GUS.

Authors' calculation based on unpublished data of the Central Statistical Office. 


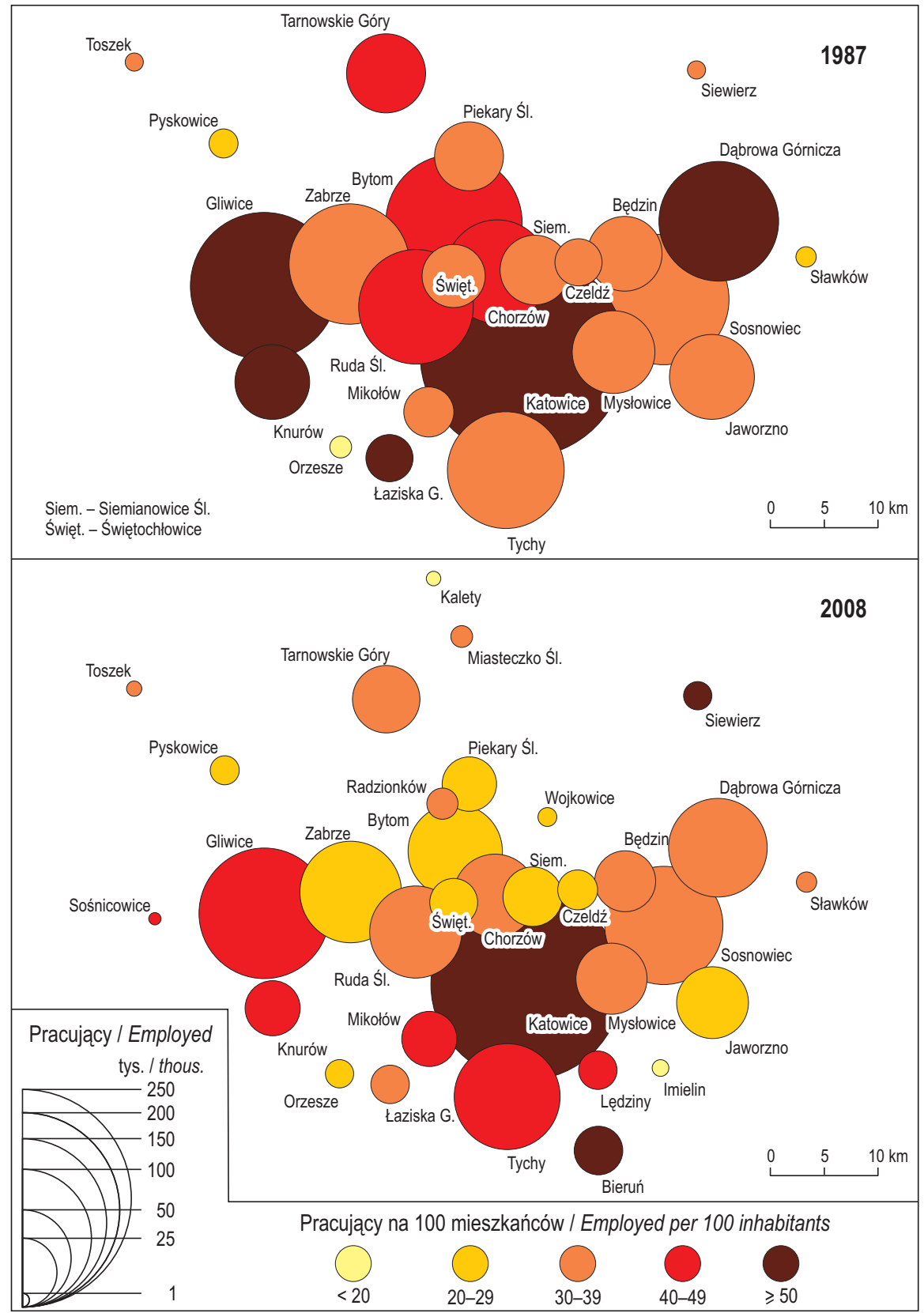

Ryc. 2. Lokalne rynki pracy w miastach konurbacji katowickiej w 1987 i 2008 r. Opracowanie własne na podstawie niepublikowanych danych GUS.

Local labour markets in Katowice Conurbation towns in the year 1987 and 2008 Authors' elaboration based on unpublished data of the Central Statistical Office. 


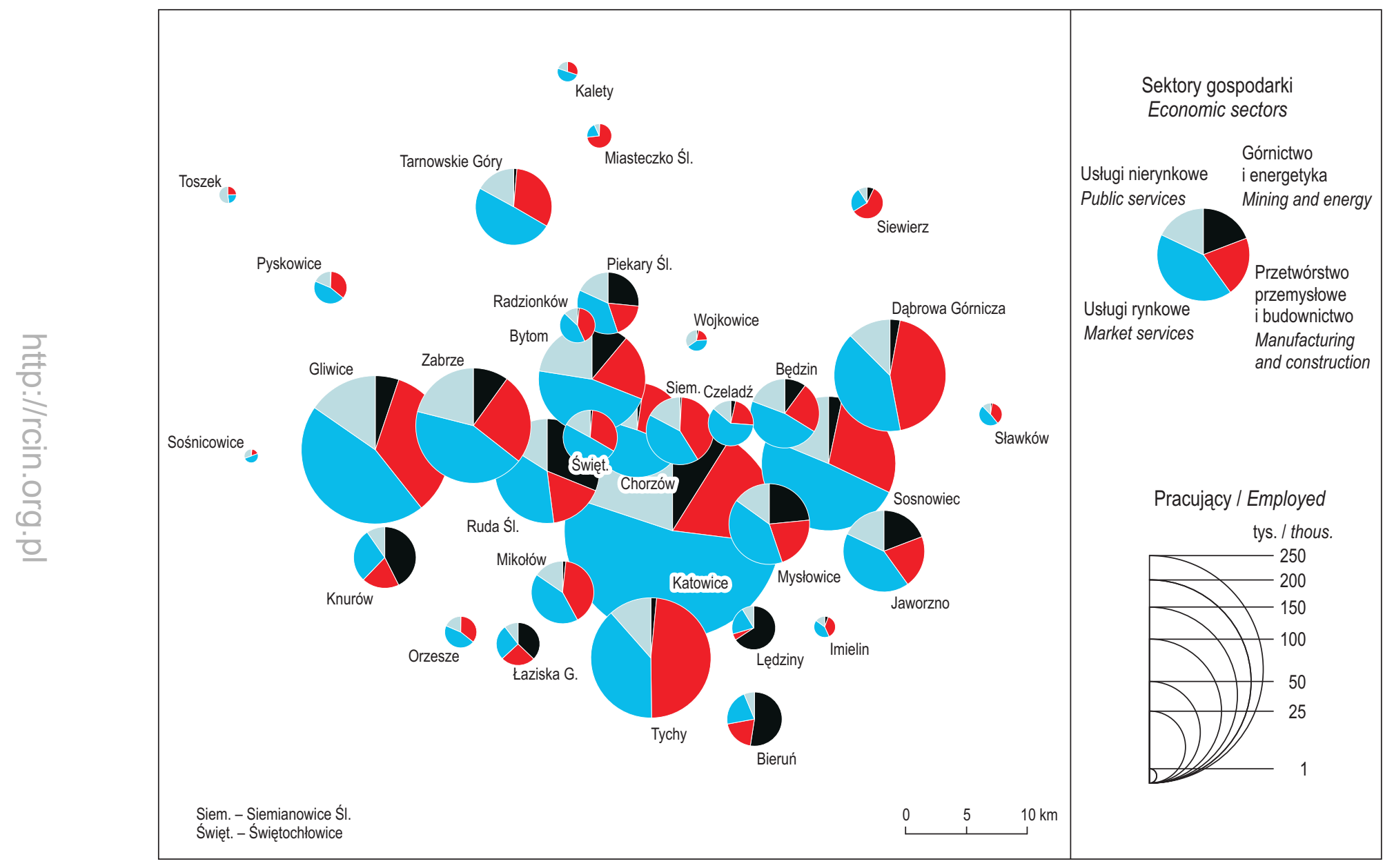


obszary mają korzystne czynniki lokalizacji, takie jak dostęp do autostrady A4, wolne tereny zielone (greenfield) pod inwestycje oraz lepsze warunki środowiska, m.in. brak szkód górniczych.

Precyzyjniejszy obraz zróżnicowania funkcjonalnego otrzymamy, porównując nie ogół pracujących w danym mieście, lecz tylko sektor egzogeniczny. Analiza stopnia rozwinięcia bazy ekonomicznej i jej dywersyfikacji (tab. 2, 3) pozwala dość wyraźnie wyróżnić dynamiczne centra gospodarki. Spośród dużych i średnich miast rdzenia wysoki udział sektora egzogenicznego cechuje Katowice (51,3\% ogółu pracujących w mieście), następnie Tychy (36,5\%) i Gliwice (33,5\%), najmniejszy zaś - Świętochłowice (2,9\%), Siemianowice Śl. (4,8\%) i Bytom (9\% pracujących w mieście). Relatywnie słabo rozwinięty jest także sektor egzogeniczny w Chorzowie, Zabrzu i Sosnowcu - jego udział wynosi między 10 a $12 \%$ ogólu pracujących ${ }^{4}$.

Nadal widoczna jest duża specjalizacja miast konurbacji katowickiej w sektorze paliwowo-energetycznym (sekcje C i E PKD 2004), oraz w przemyśle przetwórczym. Ogólnie działalności przemysłowe stanowią 45\% bazy ekonomicznej konurbacji katowickiej, przy 31-procentowym udziale w liczbie pracujących. Równocześnie aż 15 miast przemysłowych cechuje się nadal niskim lub bardzo niskim zróżnicowaniem bazy ekonomicznej (tab. 3). Wśród działalności usługowych dość powszechna jest obecność w bazie ekonomicznej miast takich branż jak handel i naprawy, transport i łączność oraz „pozostałych usług” (sekcje O, P, Q PKD 2004), jednak wyraźna specjalizacja w tych gałęziach (udział w bazie powyżej 20\%) dotyczy nie więcej niż 4-5 miast. Zdecydowanie najrzadziej w bazie ekonomicznej miast konurbacji katowickiej pojawiają się usługi finansowe, które jedynie w Katowicach mają istotne znaczenie w strukturze bazy ekonomicznej. Nieliczne miasta konurbacji mają ponadto nadwyżkę pracowników w edukacji, największe znaczenie branża ta ma w Katowicach i Gliwicach - największych ośrodkach szkolnictwa wyższego i średniego w konurbacji katowickiej.

Warto zauważyć, że porównanie „surowej” struktury pracujących oraz struktury sektora bazowego dość wyraźnie wskazuje na grupę miast, gdzie mamy do czynienia z „quasi-dywersyfikacją” gospodarczą. Polega ona na tym, że jeśli przyjrzeć się danym dotyczącym liczby pracujących w poszczególnych miastach, to sprawiają one wrażenie ośrodków silnie zdywersyfikowanych, ale zróżnicowa-

Ryc. 3. Pracujący w miastach konurbacji katowickiej według sektorów ekonomicznych w 2008 r. Opracowanie własne na podstawie niepublikowanych danych GUS.

Workplaces in Katowice Conurbation towns by economic sectors in 2008 Authors' elaboration based on unpublished data of the Central Statistical Office.

\footnotetext{
${ }^{4}$ Faktyczna wielkość bazy ekonomicznej miast jest nieco wyższa, gdyż wskaźnik nadwyżki pracowników zaniża wielkość sektora egzogenicznego dla niektórych działalności ponadlokalnych.
} 
nie to odnosi się jedynie do ich sektora endogenicznego. Spośród miast rdzenia taki charakter mają Bytom, Zabrze, Siemianowice Śl. i Świętochłowice, które pozostały miastami wyspecjalizowanymi, mimo że doświadczyły utraty dużej części bazy ekonomicznej po $1990 \mathrm{r}$.

Tabela 3. Typologia miast konurbacji katowickiej ze względu na dywersyfikację bazy ekonomicznej w $2008 \mathrm{r}$.

A typology of the towns of Katowice Conurbation based upon diversification of their basic sector in 2008

\begin{tabular}{|c|c|c|c|c|}
\hline & \multicolumn{3}{|c|}{ Poziom rozwoju sektora bazowego / Level of development of basic sector ${ }^{\mathrm{a}}$} \\
\hline & & $\begin{array}{c}\text { niski (mniej niż 15\%) } \\
\text { low (less than 15\%) }\end{array}$ & $\begin{array}{l}\text { średni }(15-30 \%) \\
\text { medium }(15-30 \%)\end{array}$ & $\begin{array}{c}\text { wysoki (więcej niż 30\%) } \\
\text { high (more than 30\%) }\end{array}$ \\
\hline \multirow{4}{*}{ 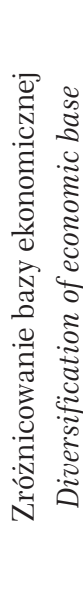 } & $\begin{array}{l}\text { wysokie } \\
\text { high } \\
(\eta<15)\end{array}$ & Chorzów & $\begin{array}{l}\text { Będzin, Tarnowskie } \\
\text { Góry }\end{array}$ & Katowice \\
\hline & $\begin{array}{l}\text { średnie } \\
\text { moderate } \\
(35>\eta \geq 15)\end{array}$ & Sosnowiec & \multirow[t]{2}{*}{$\begin{array}{l}\text { Radzionków, Sławków, } \\
\text { Mikołów }\end{array}$} & Gliwice, Sośnicowice \\
\hline & $\begin{array}{l}\text { niskie } \\
\text { low } \\
(60>\eta \geq 35)\end{array}$ & Zabrze & & $\begin{array}{l}\text { Tychy, Dąbrowa } \\
\text { Górnicza }\end{array}$ \\
\hline & $\begin{array}{l}\text { bardzo niskie } \\
\text { very low } \\
(\eta \geq 60)\end{array}$ & $\begin{array}{l}\text { Świętochłowice, } \\
\text { Orzesze, Bytom, } \\
\text { Siemianowice Śl., } \\
\text { Wojkowice, Czeladź }\end{array}$ & $\begin{array}{l}\text { Ruda Śląska, Piekary } \\
\text { Śląskie, Jaworzno, } \\
\text { Mysłowice }\end{array}$ & $\begin{array}{l}\text { Miasteczko Śląskie, } \\
\text { Lędziny, Toszek, } \\
\text { Łaziska Górne, Bieruń, } \\
\text { Knurów, Siewierz }\end{array}$ \\
\hline
\end{tabular}

${ }^{a}$ nadwyżka pracujących do ogółu pracujących w mieście. / employment surplus to all employment persons in a given town.

Źródło / Source: Gwosdz (2012).

O wytworzeniu nowej specjalizacji funkcjonalnej możemy natomiast mówić w przypadku dwóch dużych miast rdzenia: Chorzowa i Sosnowca, których baza ekonomiczna jest silnie zróżnicowana i oparta na działalnościach usługowych, przy czym jest ona dosyć płytka (tab. 2).

Największymi branżami wzrostowymi w latach 2004-2008, mierzonymi liczbą pracujących, były przemysł przetwórczy oraz obsługa nieruchomości i firm. W kategoriach bezwzględnych w latach 2004-2008 baza ekonomiczna w przetwórstwie przemysłowym wzrosła najbardziej w Tychach (6,8 tys.), Gliwicach (6,0 tys.), a następnie w Siemianowicach Śl. i Mikołowie (po około 0,7 tys.) oraz w Sosnowcu (0,5 tys.). Reindustrializacja konurbacji miała więc miejsce (podobnie jak w II połowie lat 1990.) przede wszystkim w tych miastach, któ- 
Tabela 2. Charakterystyka bazy ekonomicznej miast rdzenia konurbacji katowickiej w 2008 r.

The main characteristics of the economic base of the core towns of Katowice Conurbation in 2008

\begin{tabular}{|c|c|c|c|c|c|c|c|c|}
\hline \multirow[b]{2}{*}{$\begin{array}{l}\text { Miasto } \\
\text { Town }\end{array}$} & \multirow[b]{2}{*}{$\begin{array}{l}\text { Pracujący }^{\text {a }} \\
\text { Employed } \\
\text { persons }^{\text {a }}\end{array}$} & \multirow[b]{2}{*}{$\begin{array}{l}\text { Wielkość sek- } \\
\text { tora bazowego } \\
\text { Size of basic } \\
\text { sector }\end{array}$} & \multirow{2}{*}{$\begin{array}{l}\text { Udział sektora } \\
\text { bazowego } \\
\text { w liczbie } \\
\text { pracujących } \\
\text { Share of basic } \\
\text { sector in } \\
\text { employment }\end{array}$} & \multicolumn{4}{|c|}{$\begin{array}{c}\text { Struktura sektora bazowego (\%) } \\
\text { Structure of basic sector (\%) }\end{array}$} & \multirow{2}{*}{$\begin{array}{l}\text { Wskaźnik } \\
\text { dywersyfikacji } \\
\text { Amemiya } \\
\text { Ratio of diver- } \\
\text { sification } \\
\text { (1-100) }\end{array}$} \\
\hline & & & & $\begin{array}{l}\text { górnictwo } \\
\text { i energetyka } \\
\text { mining } \\
\text { and energy }\end{array}$ & \begin{tabular}{|c|} 
przemysł \\
przetwórczy \\
i budownictwo \\
manufacturing \\
and construc- \\
tion
\end{tabular} & $\begin{array}{l}\text { usługi } \\
\text { rynkowe } \\
\text { market } \\
\text { services }\end{array}$ & $\begin{array}{c}\text { usługi } \\
\text { nierynkowe } \\
\text { public services }\end{array}$ & \\
\hline Katowice & 191523 & 98531 & 51,3 & 14,3 & 6,7 & 59,9 & 19,2 & 5 \\
\hline Gliwice & 89471 & 30267 & 33,7 & 8,8 & 40,2 & 44,9 & 6,1 & 17 \\
\hline Sosnowiec & 73739 & 9038 & 12,2 & 2,2 & 11,1 & 74,6 & 12,1 & 23 \\
\hline Tychy & 59252 & 21701 & 36,5 & 0,0 & 76,4 & 23,1 & 0,5 & 51 \\
\hline Zabrze & 54626 & 6438 & 11,8 & 54,9 & 20,5 & 10,7 & 14,0 & 32 \\
\hline Dąbrowa Górnicza & 50903 & 13957 & 27,3 & 1,4 & 75,2 & 23,4 & 0,0 & 48 \\
\hline Bytom & 46895 & 4253 & 9,0 & 78,7 & 0,0 & 5,3 & 15,9 & 62 \\
\hline Ruda Śląska & 45014 & 12864 & 28,5 & 97,2 & 0,0 & 2,8 & 0,0 & 94 \\
\hline Chorzów & 36840 & 3718 & 10,1 & 0,0 & 9,4 & 72,4 & 18,2 & 11 \\
\hline Jaworzno & 27304 & 5035 & 18,4 & 85,0 & 0,0 & 15,0 & 0,0 & 72 \\
\hline Mysłowice & 26572 & 6411 & 24,1 & 85,2 & 0,0 & 14,5 & 0,3 & 72 \\
\hline Tarnowskie Góry & 23849 & 5856 & 24,4 & 0,0 & 28,3 & 44,0 & 27,7 & 13 \\
\hline Będzin & 19518 & 3828 & 19,5 & 36,0 & 17,8 & 35,0 & 11,1 & 14 \\
\hline Siemianowice Śląskie & 18665 & 896 & 4,8 & 0,0 & 100,0 & 0,0 & 0,0 & 64 \\
\hline Piekary Śląskie & 15625 & 3880 & 24,8 & 91,3 & 0,0 & 3,7 & 5,0 & 82 \\
\hline Świętochłowice & 12156 & 349 & 2,9 & 0,0 & 0,0 & 100,0 & 0,0 & 100 \\
\hline Czeladź & 8268 & 1000 & 12,0 & 0,0 & 0,0 & 100,0 & 0,0 & 94 \\
\hline $\begin{array}{l}\text { Razem strefa rdzeniowa } \\
\text { Core zone, total }\end{array}$ & 800220 & 228022 & 28,5 & 8,9 & 27,2 & 46,0 & 17,9 & $\mathrm{x}$ \\
\hline $\begin{array}{l}\text { Konurbacja katowicka } \\
\text { Katowice Conurbation }\end{array}$ & 887508 & 261230 & 29,4 & 31,2 & 26,0 & 30,8 & 12,0 & $\mathrm{x}$ \\
\hline
\end{tabular}

${ }^{a}$ wliczając pracujących w mikrofirmach. / including working in microcompanies.

Opracowanie własne na podstawie niepublikowanych danych GUS.

Authors' elaboration based on unpublished data of the Central Statistical Office. 
re mają obszary inwestycyjne w ramach Katowickiej Specjalnej Strefy Ekonomicznej i napędzana była głównie inwestycjami producentów samochodów i ich części. W efekcie, miasta konurbacji są obecnie największym skupieniem przemysłu motoryzacyjnego w Polsce, zatrudniając 35,2 tys. osób (17\% pracujących w Polsce) i generując 30\% jej przychodów (Gwosdz i Micek, 2010).

Silnie wzrostową branżą była także obsługa nieruchomości i firm (7,0 tys.), jednak jej wzrost był silnie skoncentrowany i ograniczył się do czterech miast: Katowic (4,4 tys.), Gliwic (2,3 tys.), Sosnowca (1,3 tys.) oraz Tych (0,4 tys.).

\section{Ranga miast konurbacji katowickiej w zakresie funkcji centralnych}

Z powodu słabości sektora usługowego i genezy funkcjonalnej (układ miast wyspecjalizowanych), do lat 1990. konurbację katowicką charakteryzowała słaba hierarchizacja ośrodków (Rajman, 1997). W okresie międzywojennym spośród kilku równorzędnych miast wybiły się Katowice, które po 1945 r. silnie wzmocniły swą pozycję w stosunku do głównych ośrodków usługowych i górnośląskiej (Gliwic i Bytomia), i zagłębiowskiej (Sosnowca i Będzina) części konurbacji.

Współcześnie, wobec silnej przebudowy tradycyjnej bazy przemysłowej, coraz większe znaczenie ma zdolność wykreowania dynamicznych działalności ponadlokalnych w sektorze usług, w tym zaliczanych do funkcji metropolitalnych (zob. Szajnowska-Wysocka, 2011). Pod tym względem niekwestionowana jest pozycja Katowic, które skupiają 60\% usługowego sektora egzogenicznego w konurbacji (77,9 tys. z 130 tys.), sześć razy więcej niż Gliwice, które można w tym wypadku traktować jak ośrodek drugiego rzędu. Gliwice z kolei mają dużą przewagę nad Sosnowcem - trzecim w tej kategorii ośrodkiem konurbacji. Znaczącą rolę odgrywają ponadto Tychy, Tarnowskie Góry, Chorzów i Dąbrowa Górnicza (między 3,9\% a 2,5\% nadwyżki zatrudnionych w usługach w konurbacji), wyprzedzając pod tym względem Mikołów, Będzin, Zabrze i Bytom, z udziałem od 0,7\% do 1,5\%.

Ogólnie rzecz biorąc, silną albo ponadprzeciętną pozycję mają dwa typy miast: ośrodki rdzenia i strefy wewnętrznej o starszych niż XIX-wieczne tradycjach miejskości oraz wykształconym historycznie zapleczu (Gliwice, Mikołów, Tarnowskie Góry, Będzin), a także takie, które zdołały przejąć funkcje od otaczających je ośrodków przemysłowych i starszych miast (Katowice, Gliwice i Sosnowiec).

Relatywnie niska i bardzo niska ranga cechuje miasta, które od początku industrializacji były monofunkcyjnymi miastami fabrycznymi (Zabrze, Świętochłowice, Siemianowice, Jaworzno, Ruda Śląska, Piekary Śląskie). Wyraźny deficyt widoczny jest także w miastach, które zostały zdominowane przez przemysł po 1945 r. (Bytom, Sosnowiec). Co istotne, największy deficyt funkcji usługowych (w stosunku do liczby ludności) występuje w czterech dużych miastach: Bytomiu, Sosnowcu, Zabrzu i Rudzie Śląskiej (ryc. 4), przy czym, 


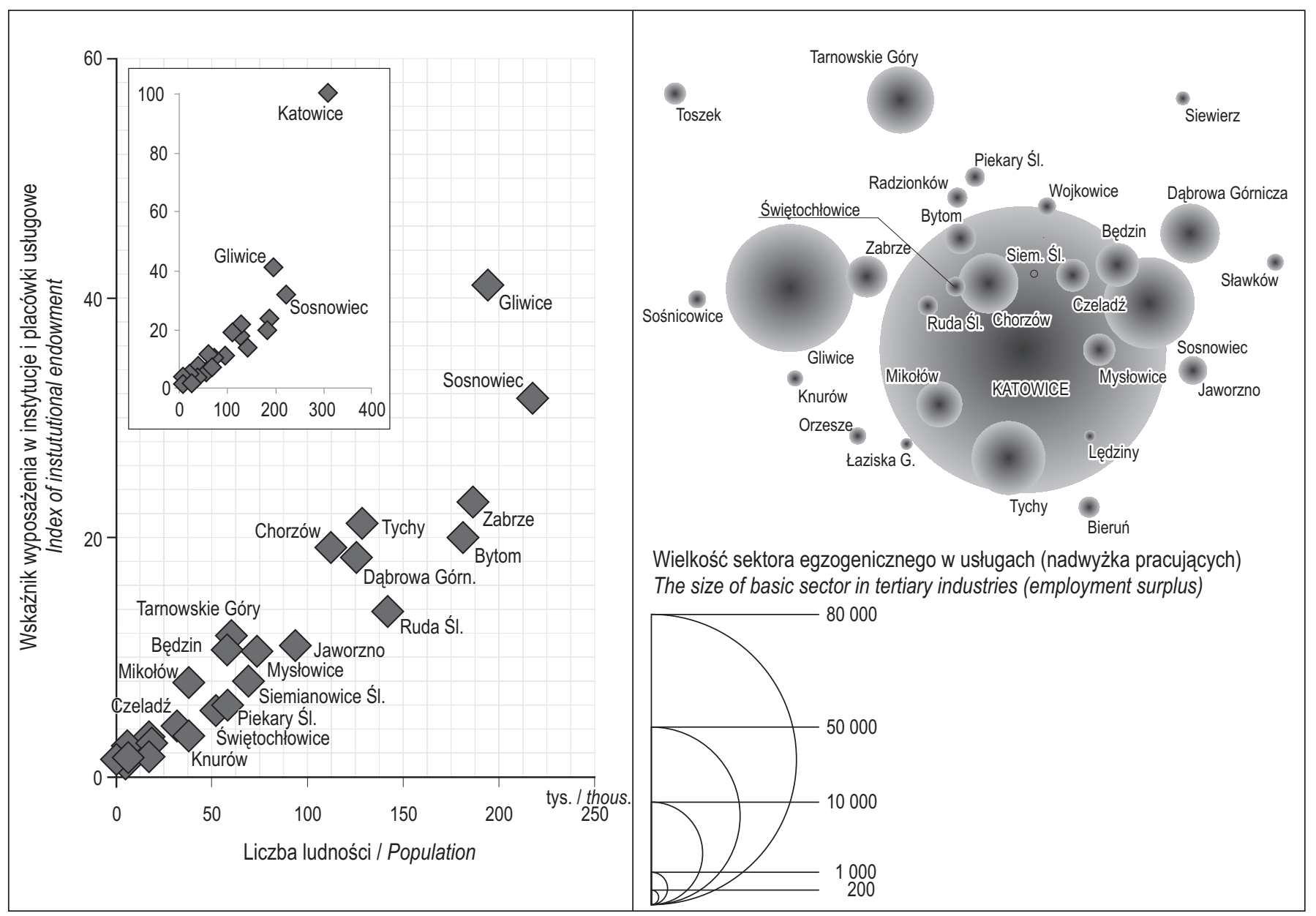


paradoksalnie - trzy z nich oprócz Rudy Śląskiej - w sensie struktury liczby pracujących są ośrodkami usługowymi (!). Analiza bazy ekonomicznej wskazuje jednak wyraźnie, że większość tych działalności ma charakter wyłącznie endogeniczny. Ograniczona możliwość stworzenia własnego zaplecza sprawia, że choć miasta te w zasadzie strukturalnie nie różnią się od najsilniejszych ośrodków usługowych konurbacji - np. odsetek pracujących w usługach w Bytomiu to 69\%, a w Katowicach 73\% - jednak ich słabość widać w bezwzględnej wielkości egzogenicznego sektora w usługach (ryc. 4).

Dezagregacja na poziomie sekcji PKD nie pozwala niestety uchwycić precyzyjnie rangi miast, jeśli chodzi o tzw. usługi oparte na wiedzy oraz tzw. działalności kreatywne, nazywane przez niektórych autorów „nową gospodarką” (Klasik, 2008), lecz nawet na poziomie sekcji PKD widać wyraźnie silną koncentrację tzw. usług metropolitalnych (finanse, obsługa nieruchomości i firm oraz szkolnictwo wyższe), gdzie sześć miast skupia ponad 98\% sektora bazowego w tych działalnościach. Wiodącą rolę odgrywają Katowice, a następnie Gliwice, Sosnowiec oraz Tychy, Chorzów i Dąbrowa Górnicza. Duża koncentracja usług dla przedsiębiorstw w Katowicach (56\% całości konurbacji), pozycja miasta jako siedzib zarządu firm (Śleszyński, 2007), a także m.in. fakt, że miasto to jako jedyne ma nadwyżkę zatrudnionych w sektorze finansowym (6,5 tys. osób), wyraźnie potwierdzają rolę Katowic jako city dla całej konurbacji.

\section{Powiązania między miastami w świetle dojazdów do pracy}

Powiązania między miastami w układach policentrycznych cechują się dużą złożonością wynikającą m.in. z ich skali, dyspersji kierunków, wzajemnego nakładania się powiązań (koincydencji) oraz oddziaływania możliwości pośrednich (Runge, 1991). W tym złożonym obszarze można jednak wskazać na kilka wiodących prawidłowości. Pierwszą jest duże znaczenie Katowic jako głównego ośrodka organizującego sieć powiązań w zakresie dojazdów do pracy (ryc. 5). Katowice są dla wszystkich miast konurbacji jednym z trzech kierunków wiodących, najczęściej najważniejszym lub drugim co do ważności. Powiązania między Katowicami a pozostałymi miastami w zakresie dojazdów do pracy są przy tym najczęściej silnie asymetryczne (zdecydowana przewaga przyjazdów do Katowic), co pozwala wnioskować o silnej strukturze hierarchicznej powiązań. Dość zrównoważone relacje wiążą Katowice z Gliwicami, Chorzowem, Mikołowem i Mysłowicami.

Ryc. 4. Ranga miast konurbacji katowickiej pod względem wyposażenia w działalności usługowe Opracowanie własne na podstawie niepublikowanych danych GUS.

The importance of Katowice Conurbation as regards service activity Authors' elaboration based on unpublished data of the Central Statistical Office. 


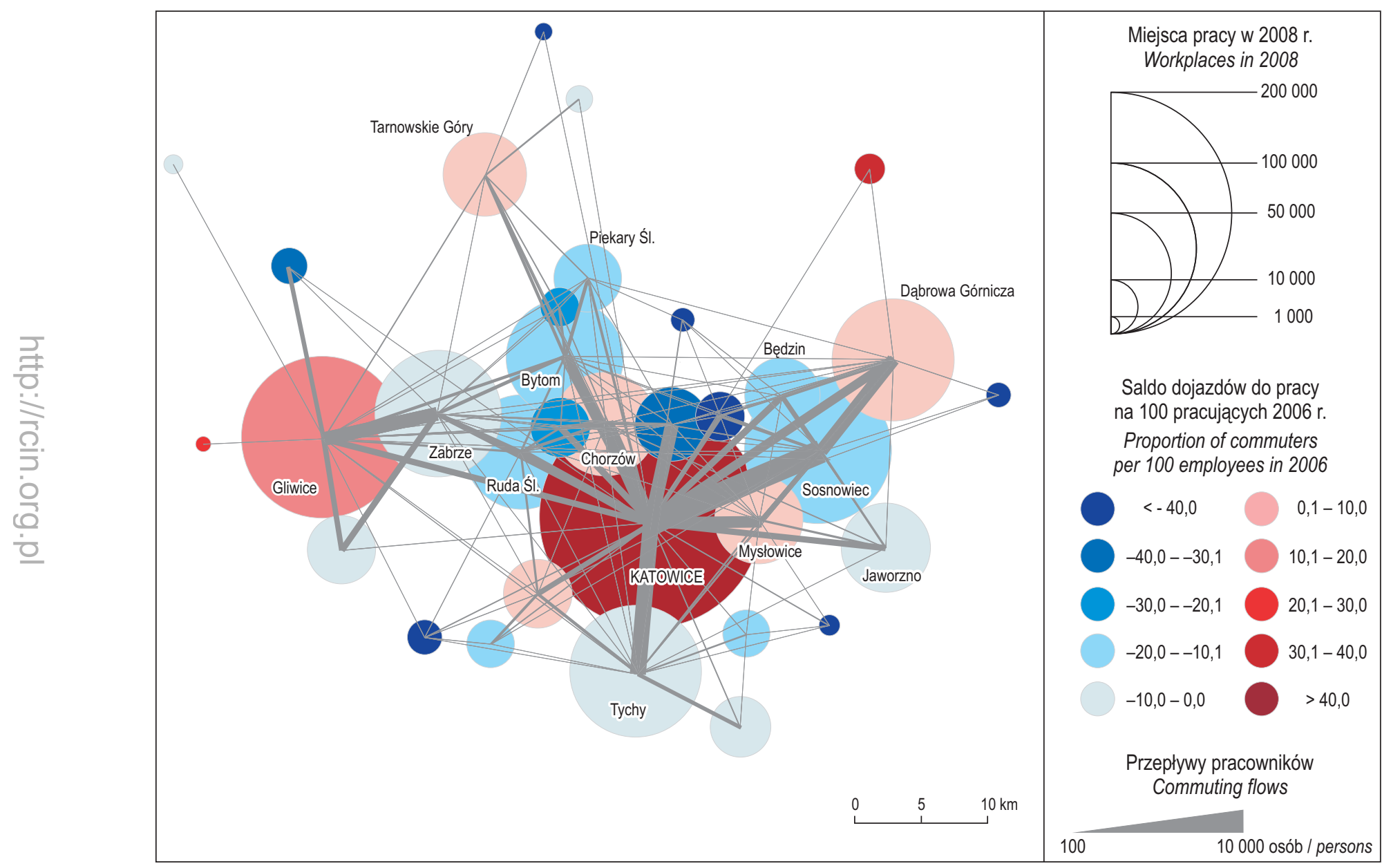


W skali całej konurbacji wyróżniają się silne wzajemne powiązania w trójkącie miast części górnośląskiej (Gliwice-Zabrze-Knurów) oraz zagłębiowskiej (Sosnowiec-Dąbrowa Górnicza-Będzin). Pierwszy z tych układów cechuje się dominującą pozycją Gliwic, ponadto wyraźnie ciążą do niego Pyskowice i Toszek (można tu mówić o relacjach wyraźnego podporządkowania) oraz Sośnicowice (relacja dość zrównoważona). Ponieważ Gliwice spośród wszystkich miast konurbacji mają ujemne saldo dojazdów do pracy jedynie z Katowicami, a ich pozycja wobec sąsiadujących miast jest wyraźnie nadrzędna, możemy je uznać za drugi po Katowicach ośrodek dominujący, co potwierdza zresztą wysoka przewaga liczby przyjeżdżających nad wyjeżdżającymi. Z kolei wzajemne powiązania miast zagłębiowskich są zrównoważone (wzajemne salda wyjazdów/dojazdów zawierają się między 0,9 a 1,5), przy czym globalną nadwyżkę dojeżdżających nad wyjeżdżającymi do pracy ma z tych miast jedynie Dąbrowa Górnicza (ryc. 5).

Stosunkowo słabe są wzajemne powiązania miast górnośląskiej części rdzenia, położonych między Katowicami a Gliwicami i Tarnowskimi Górami. Potwierdza to tezę o słabych powiązaniach w układach miast o dużym podobieństwie struktury bazy ekonomicznej - dotyczy to w szczególności wzajemnych powiązań między Zabrzem, Rudą Śląską, Bytomiem i Świętochłowicami. Po raz kolejny potwierdza się regresja pozycji Bytomia, który historycznie - a nawet jeszcze w latach 1980. (Runge, 1991) - był wiodącym ośrodkiem w tej części konurbacji. Obecnie ma on nadrzędną relację jedynie z Piekarami Śląskimi, zrównoważoną - ze Świętochłowicami i Rudą Śląską, natomiast silnie ujemne saldo dojazdów - w powiązaniach nie tylko z Katowicami i Gliwicami, ale też z Zabrzem, Chorzowem i Tarnowskimi Górami.

Miasta o dominacji wyspecjalizowanej funkcji przemysłowej, nawet jeśli mają wysokie nadwyżki w tym sektorze, cechuje najczęściej ujemne saldo dojazdów (ryc. 5) - wyjątkami są Mysłowice, Dąbrowa Górnicza i Siewierz. Dodatnim saldem migracji poza wspomnianymi wyżej wiodącymi ośrodkami gospodarczymi rdzenia o dużej, a jednocześnie zróżnicowanej bazie ekonomicznej - Katowicami i Gliwicami - odznaczają się polifunkcyjne ośrodki powiatowe strefy peryferyjnej (Tarnowskie Góry i Mikołów). Wysokie ujemne saldo dojazdów oraz niewielka własna baza ekonomiczna wskazuje, że 9 miast (Wojkowice, Sławków, Imielin, Czeladź, Orzesze, Radzionków, Pyskowice, Siemianowice Śl. i Świętochłowice) pełni głównie rolę ośrodków mieszkaniowych dla sąsiadujących z nimi miejscowości silniejszych gospodarczo. Zwraca uwagę przypadek Chorzowa, który mimo niewielkiej bazy ekonomicznej ma dodatnie saldo zarów-

Ryc. 5. Dojazdy do pracy w konurbacji katowickiej

Opracowanie własne na podstawie niepublikowanych danych GUS.

Commuter flows in the Katowice Conurbation

Authors' elaboration based on unpublished data of the Central Statistical Office. 
no dla dojazdów ogółem, jak i w relacjach ze wszystkimi sąsiednimi miastami oprócz Katowic. Natomiast Tychy, mimo silnej bazy, wykazują niewielkie ujemne globalne saldo dojazdów do pracy. Fakt ten można interpretować w ten sposób, że gros bazy ekonomicznej tworzą w Tychach miejsca pracy w przemyśle przetwórczym, tymczasem wielu mieszkańców Tych znajduje zatrudnienie w sektorze usług w Katowicach.

\section{Wnioski}

Konurbacja katowicka przeszła po 1989 r. głęboką zmianę organizacji wewnętrznej, która w szczególny sposób dotknęła jej strefę rdzeniową. Odwołując się do typów historycznych aglomeracji zaproponowanych przez N. Phelpsa i T. Ozawę (2003), współczesna organizacja konurbacji pozwala zaliczyć ją raczej do typu późnoindustrialnego, opisanego przez A.J. Scotta (1982), niż postindustrialnego à la P.G. Hall (1997). Wyrazem tego stadium jest ciągle duży udział działalności przemysłowej w bazie ekonomicznej konurbacji (45\%) przy jednoczesnym silnym podziale pracy między usługowym centrum aglomeracji (city) a pozostałymi ośrodkami węzłowymi, głównie o charakterze przemysłowym i przemysłowo-usługowym. Po drugie, w przeciwieństwie do formy aglomeracji postindustrialnej, w konurbacji katowickiej w ostatnich dwóch dekadach dochodziło do wzmacniania usługowego rdzenia aglomeracji (Katowic), bez oznak selektywnej dekoncentracji działalności usługowych do strefy krawędziowej. Po trzecie, późnoindustrialny charakter konurbacji katowickiej potwierdzają tendencje rozwoju jej bazy ekonomicznej w latach 2000. Główną wzrostową działalnością egzogeniczną był w konurbacji przede wszystkim przemysł przetwórczy średniowysokich technologii (głównie produkcja samochodów i ich części), a następnie usługi dla przedsiębiorstw - te ostatnie będące m.in. wynikiem efektów mnożnikowych generowanych przez zakłady produkcyjne. Tym samym konurbacja katowicka wyraźnie różni się od takich ośrodków metropolitalnych jak Warszawa czy Kraków, gdzie wzrostowym sektorem egzogenicznym były w latach 2000. były działalności usługowe.

Współczesną organizację przestrzenno-funkcjonalną konurbacji katowickiej można opisać następująco: rolę city w skali całego obszaru metropolitalnego pełnią Katowice, silnie zintegrowane z dwoma subcentrami usługowymi rdzenia (miastami wspomagającymi), którą to funkcję pełnią Sosnowiec oraz Chorzów (ryc. 6). Dwa ostatnie miasta są w fazie postindustrialnej - przy czym ich baza ekonomiczna jest na razie bardzo płytka. Na krawędzi strefy rdzeniowej istnieją wyspecjalizowane ośrodki przemysłowe, w których zlokalizowana jest większość

Ryc. 6. Przestrzenno-funkcjonalny model konurbacji katowickiej

The functional model of the Katowice Conurbation

Opracowanie własne. / Authors' own elaboration. 


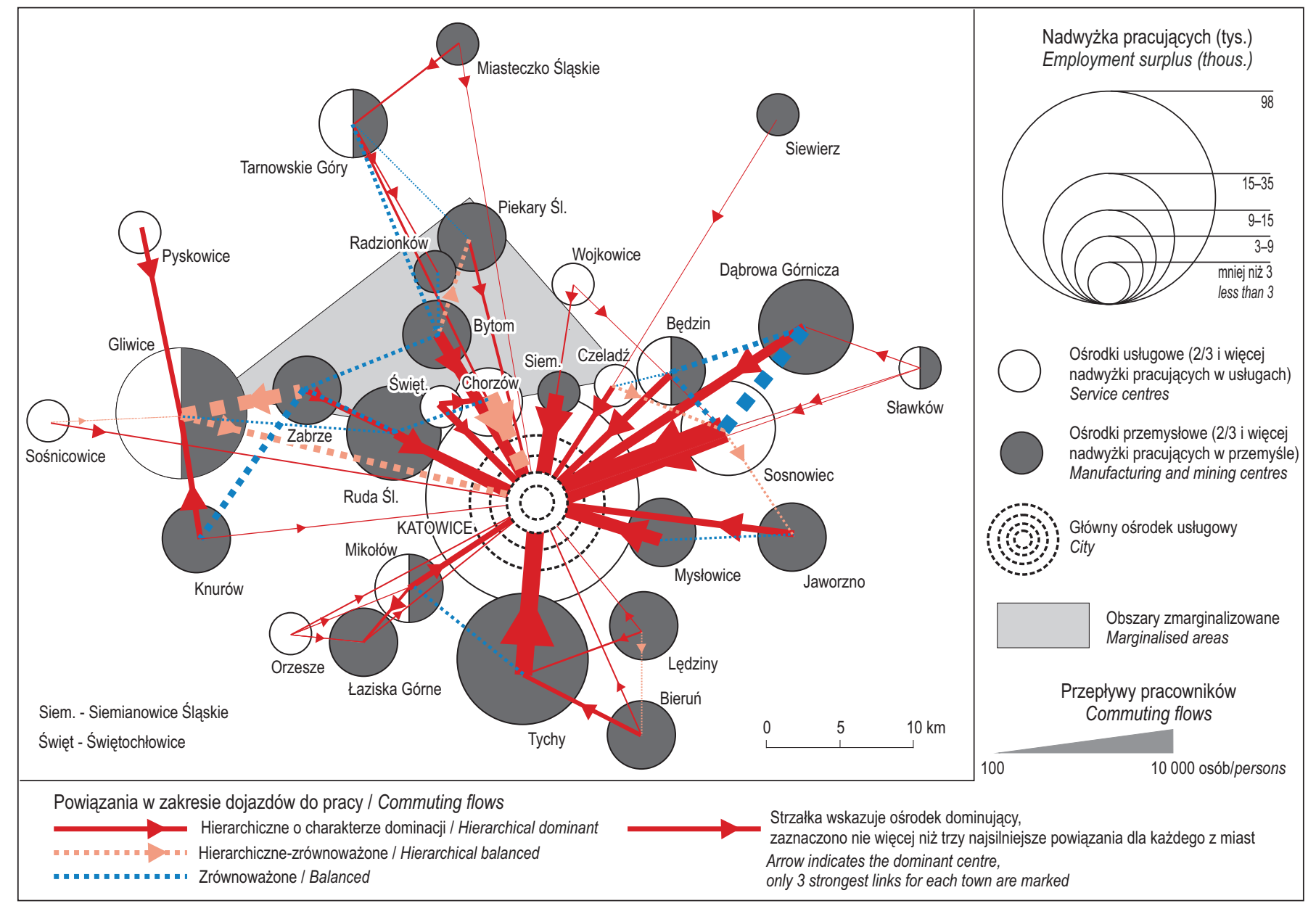


nowych inwestycji w przemyśle - rolę tę pełnią głównie strefy inwestycyjne w Tychach i Gliwicach, w mniejszym stopniu w Dąbrowie Górniczej. Dodatkowo funkcjonują ośrodki przemysłowe związane z działalnością branż tradycyjnych, m.in. Ruda Śląska (górnictwo) oraz Dąbrowa Górnicza (hutnictwo). Gliwice pełnią złożoną rolę zarówno silnego ośrodka usługowego organizującego powiązania o charakterze hierarchicznym (dla sąsiadujących miast oraz rolniczego zaplecza), jak i wyspecjalizowanego ośrodka przemysłowego. W sumie Gliwice są drugim miastem konurbacji katowickiej, które ma wszystkie cechy bieguna wzrostu (Sobala-Gwosdz, 2010). Dwa duże ośrodki konurbacji (Zabrze i Bytom) zostały zmarginalizowane w związku z regresem bazy przemysłowej, któremu nie towarzyszył adekwatny wzrost innych działalności. Utrata bazy ekonomicznej przez średnie miasta rdzenia - Świętochłowice i Siemianowice Śl. zepchnęła je do de facto roli ośrodków satelitarnych. Natomiast umiarkowany sukces $\mathrm{w}$ budowie postindustrialnych podstaw rozwoju osiągnął Będzin, który ma dość wyraźne zaplecze i zrównoważone relacje zarówno z Sosnowcem, jak i z Dąbrową Górniczą. W strefie peryferyjnej konurbacji, dość silnie powiązanej z rdzeniem, dominującymi ogniwami są dwa miasta powiatowe o polifunkcyjnej strukturze gospodarki - Tarnowskie Góry i Mikołów. Poza tym znajdujemy w tej strefie głównie monofunkcyjne ośrodki przemysłowe: Knurów, Łaziska Górne, Lędziny, Bieruń, Miasteczko Śląskie i Siewierz oraz silnie wyspecjalizowane miasta usługowe: Wojkowice, Czeladź, Sławków i Toszek, przy czym niektóre z nich mają dość silne cechy miast satelitarnych. Wybitnie mieszkaniowy charakter mają cztery inne ośrodki strefy peryferyjnej (Imielin, Pyskowice, Kalety, Orzesze). Trzeba zaznaczyć, że na poziomie usług podstawowych i średniego szczebla, co wykazano w innych badaniach na przykładzie dojazdów do szkół średnich (Sobala-Gwosdz, 2010), średnie i duże miasta rdzenia zachowują dość dużą samodzielność (są „klonami” w terminologii E. Meijersa (2007)).

Obserwujemy dwa główne procesy wpływające na zorganizowanie funkcjonalno-przestrzenne konurbacji. Pierwszym z nich jest postępująca koncentracja usług wyższego rzędu w Katowicach, która sprzyja wytworzeniu silnych więzi hierarchicznych w skali całego regionu miejskiego. Natomiast rozmieszczenie funkcji przemysłowej - ciągle bardzo istotnej - oraz rzecz jasna ludności podtrzymuje policentryczny charakter omawianej formy osadniczej. W perspektywie najbliższej dekady tendencja ta będzie się zapewne utrzymywać, gdyż obecnie brak przesłanek pozwalających wnioskować o dekoncentracji funkcji usługowych, a jednocześnie utrzymywaniu się procesów reindustrializacji, które obejmują głównie tereny greenfield (Gliwice, Tychy), ale także obszary poprzemysłowe (brownfields) w niektórych miastach rdzenia (Sosnowiec, Siemianowice Śląskie). Drugi wyraźny proces dotyczy wzrostu znaczenia południowej i zewnętrznej strefy konurbacji. W tym względzie należy wskazać na organizującą rolę gospodarczo-przestrzenną głównych korytarzy transportowych, przede wszystkim autostrady A4. 
Obserwowane po 1989 r. procesy wpisują się w opisywany przez M. Grochowskiego (2011) model relacji o charakterze zależności hierarchicznej. Katowice, jako ośrodek dominujący, systematycznie przejmują dynamiczne funkcje usługowe o charakterze ponadlokalnym, ograniczając w innych miastach rdzeniowych możliwości ich wykształcenia. Proces ten wskazuje, że w warunkach neoliberalnej fazy rozwoju po 1989 r. w konurbacji katowickiej mieliśmy do czynienia z „pasywną metropolizacją” związaną z mało efektywnym zarządzaniem, czy wręcz brakiem zarządzania w skali obszaru metropolitalnego. Obserwację tę potwierdzają wyniki badań R. Krzysztofika i innych (2012), którzy wykazali, że relacja między władzami lokalnymi wiodących miast rdzenia w zakresie działań na rynku pracy jest „raczej negatywna”, a najczęściej „nieistotna i słaba”.

Jakkolwiek dotychczas nie sprawdziły się pesymistyczne prognozy dotyczące współczesnego rozwoju ekonomicznego konurbacji katowickiej (zob. Gorzelak, 2003), to stojące przed tym regionem miejskim wyzwania w zakresie rozwoju funkcjonalno-przestrzennego są nadal ogromne. Naszym zdaniem dwa główne z nich to: (1) równoważenie rozwoju konurbacji katowickiej w ujęciu modelu sieciowego (komplementarność funkcjonalna), a w szczególności odbudowa pozycji miast północnej części rdzenia, zwłaszcza Bytomia; (2) dalsze umacnianie i dywersyfikacja bazy ekonomicznej wobec faktu, że duża część miast to nadal silnie wyspecjalizowane ośrodki przemysłowe. Wyzwania te potęguje fakt, że konurbacji katowickiej dotyczy obecnie silna depopulacja (Krzysztofik i Runge, 2011).

\section{Piśmiennictwo}

Alonso W., 1973, Urban zero population growth, Daedalus, 109, s. 191-206.

Blotevogel H., 1983, Die Städtesystem in Nordrhein-Westfalen, [w:] P. Schreiber, F. Weber (red.), Westfalen und angrenzende Regionen, Festschrift zum 44. Deutschen Geographentag in Münster, 1, Padeborn, s. 71-104.

Domański B., 2003, Economic trajectory, path dependency and strategic intervention in an old industrial region: the case of Upper Silesia, [w:] R. Domański (red.), Recent advances in urban and regional studies, Polish Academy of Sciences, Committee for Space Economy and Regional Planning, Warszawa, s. 133-153.

Dulias R., Hibszer A. (red.), 2008, Górnośląski Zwiazek Metropolitalny. Zarys geograficzny, PTG Oddział Katowicki, Sosnowiec.

Dziatalność gospodarcza przedsiębiorstw o liczbie pracujacych do 9 osób w 2008 r., 2009, Główny Urząd Statystyczny, Warszawa.

Działek J., Ciechowski M., Gwosdz K., 2010, Ranga miast w świetle wyposażenia w instytucje i ustugi dla firm. Badanie funkcji, potencjału oraz trendów rozwojowych miast w województwie matopolskim,

http://www.politykarozwoju.obserwatoria.malopolska.pl/CmsContent.mvc/GetArticle/10/4. (1.02.2012).

Dziewoński K., Jerczyński M., 1978, Theory, methods of analysis and historical development of national settlement systems, Geographia Polonica, 29, s. 201-209. 
Gorzelak G., 2003, Bieda i zamożność regionów, [w:] I. Sagan, M. Czepczyński (red.), Wymiar i wspótczesne interpretacje regionu, Katedra Geografii Ekonomicznej, Uniwersytet Gdański, Gdańsk-Poznań, s. 57-77.

Grochowski M., 2011, Functional linkages as a stimulating factor in metropolis development, [w:] T. Komornicki, P. Siłka (red.), Functional Linkages between Polish Metropolises, Studia Regionalia, 29, Warszawa, s. 20-34.

Gwosdz K., 2004, Ewolucja rangi miejscowości w konurbacji przemystowej. Przypadek Górnego Śląska (1830-2000), Instytut Geografii i Gospodarki Przestrzennej Uniwersytetu Jagiellońskiego, Kraków.

-, 2012, Baza ekonomiczna i specjalizacja funkcjonalna miast konurbacji katowickiej po dwu dekadach transformacji, Acta Geographica Silesiana, 11, s. 15-30.

Gwosdz K., Micek G., 2010, Spatial agglomerations in the Polish automotive industry, Przegląd Geograficzny, 82, 2, s. 159-190.

Hall P. G., 1997, Modelling the post-industrial city, Futures, 29, s. 311-22.

Klasik A. (red.), 1987, Kształtowanie tradycyjnego regionu przemystowego, Studia nad Ekonomiką Regionu, 16, Śląski Instytut Naukowy, Katowice.

-, 2008, Aktywność przedsiębiorcza i konkurencyjność ekonomiczna miast w procesie restrukturyzacji aglomeracji miejskich, Wydawnictwo Akademii Ekonomicznej w Katowicach, Katowice.

Klasik A., Kuźnik F., 2008, Aglomeracja górnośląska wobec wyzwań przyszłości, [w:] T. Marszał (red.), Rola polskich aglomeracji wobec wyzwań Strategii Lizbońskiej, Studia KPZK PAN, 120, s. 152-179.

Kłosowski F., Runge J., Prokop R., 1996, Cechy struktury przestrzenno-funkcjonalnej województwa katowickiego i ostrawsko-karwińskiego regionu przemystowego, Czasopismo Geograficzne, 67, 3-4, s. 345-364.

Korcelli P., 2011, Inter-metropolitan linkages: selected concepts and policy applications, [w:] T. Komornicki, P. Siłka (red.), Functional linkages between Polish Metropolises, Studia Regionalia, 29, Polish Academy of Sciences, Committee for Spatial Economy and Regional Planning, Warszawa, s. 10-20.

Kruszka K. (red.), 2010, Dojazdy do pracy w Polsce. Terytorialna identyfikacja przeptywów ludności związanych z zatrudnieniem w 2006 r., Główny Urząd Statystyczny, Urząd Statystyczny w Poznaniu, Poznań.

Krzysztofik R., Runge J., 2011, Delimitacja Regionu Górnośląsko-Zagtębiowskiej Metropolii „Silesia”, Sosnowiec

http://www.silesiametropolia.eu/images/stories/01pdf/Delimitacja\%20regionu\%20GZM\%20Silesia.pdf (13.02.2012).

Krzysztofik R., Runge J., Kantor-Pietraga I., 2011, Paths of Shrinkage in the Katowice Conurbation. Case Studies of Bytom and Sosnowiec Cities, WNoZ Uniwersytet Śląski, Sosnowiec.

-, 2012, An Introduction to Governance of Urban Shrinkage. A Case of Two Polish Cities: Bytom and Sosnowiec, WNoZ, Uniwersytet Śląski, Sosnowiec.

Kukliński A., 2008, Problematyka przyszłości regionów. Piętnaście komentarzy. W poszukiwaniu nowego paradygmatu, Ministerstwo Rozwoju Regionalnego, Warszawa.

Liszewski S., Maik W., 2000, Osadnictwo. Wielka Encyklopedia Geografii Świata, 19, Wydawnictwo Kurpisz, Poznań.

Meijers E., 2007, Clones or complements? The division of labour between the main cities of the Randstad, the Flemish Diamond and the RheinRuhr Area, Regional Studies, 41, 7, s. 889-900. 
Mikołajec J., 2008, Spatial restructuring of the Katowice Conurbation, [w:] M. Nowak, M. Nowosielski (red.), Declining Cities/Developing Cities: Polish and German Perspectives, Wydawnictwo Instytutu Zachodniego, Poznań, s. 101-112.

Phelps N. A., Ozawa T., 2003, Contrasts in agglomeration: proto-industrial, industrial and post-industrial forms compared, Progress in Human Geography, 27, 5, s. 583-604.

Rajman J., 1997, Struktura przestrzenna ludności i osadnictwa aglomeracji katowickiej w okresie transformacji gospodarczej, Zeszyty IGiPZ PAN, 46, s. 39-52.

Runge J., 1991, Dojazdy do pracy w przestrzennej strukturze powiazań miast województwa katowickiego, Prace Naukowe Uniwersytetu Śląskiego w Katowicach, 1198.

-, 2007, Region tradycyjny Europy Środkowej i jego problemy w okresie transformacji ustrojowo-gospodarczej, [w:] I. Kiniorska, S. Sala (red.), Rola geografii spoteczno-ekonomicznej w badaniach regionalnych, Instytut Geografii Akademii Świętokrzyskiej im. Jana Kochanowskiego, Oddział Kielecki PTG, Kielce, s. 15-26.

-, 2009, Katowice region in the light of the selected conceptions of social-economic transformations, Bulletin of Geography, Socio-Economic Series, 11, s. 31-48.

-, 2011, Miasta tradycyjnego regionu społeczno-ekonomicznego, [w:] S. Kaczmarek (red.), Miasto. Ksiega Jubileuszowa w 70. rocznice urodzin profesora Stanistawa Liszewskiego, Uniwersytet Łódzki, Łódź, s. 133-142.

Runge J., Krzysztofik R., Spórna T., Cechy specyficzne umiastowienia województwa ślaskiego na przełomie XX $i$ XXI wieku, [w:] K. Sikora., D. Sokołowski (red.), Koncepcje i problemy badawcze geografii, Wyższa Szkoła Gospodarki, Bydgoszcz, s. 251-269.

Runge J., Żurek I., 2010, Procesy $i$ struktury demograficzno-społeczne na obszarze województwa śląskiego w latach 1988-2008, Urząd Statystyczny, Katowice.

Schöller P., Blotenvogel H., Buchholz H.J., Hommel M., Schilling-Kaletsch I., 1984, The settlement system of the Federal Republic of Germany, [w:] L.S. Bourne, R. Sinclair, K. Dziewoński (red.), Urbanization and Settlement Systems. International Perspectives, Oxford University Press, London, s. 178-199.

Scott A.J., 1982, Locational patterns and dynamics of industrial activity in the modern Metropolis, Urban Studies, 19, s. 111-142.

Sobala-Gwosdz A. (red.), 2010, Badanie trendów rozwojowych w województwie śląsim poprzez wyznaczenie ośrodków wzrostu i obszarów stagnacji, Strada Konsulting, Bielsko-Biała.

Sokołowski D., 2008, Baza ekonomiczna większych miast w Polsce w okresie transformacji systemowej, Przegląd Geograficzny, 80, 2, s. 245-264.

Spórna T., 2012, Modele przemian urbanizacyjnych w województwie ślaskim, Uniwersytet Śląski, Sosnowiec.

Szajnowska-Wysocka A., 2011, Od konurbacji górnośląskiej do metropolii „Silesia”, Przekształcenia Regionalnych Struktur Funkcjonalno-Przestrzennych, Instytut Geografii i Rozwoju Regionalnego Uniwersytetu Wrocławskiego, 20, 2, s. 119-132.

Szczepański M., Gawron G., Rojek-Adamek P. (red.), 2011, Od badania do działania: analiza trendów rozwojowych i zmian gospodarczych w obszarze Górnoślaskiego Zwiazku Metropolitalnego, Wyższa Szkoła Zarządzania i Nauk Społecznych im. ks. Emila Szramka, Tychy.

Śleszyński P., 2007, Gospodarcze funkcje kontrolne w przestrzeni Polski, Prace Geograficzne, PAN IGiPZ, 213, Warszawa.

Tkocz M., 2009, Tendencje zmian w strukturze przemystu w miastach Górnoślasko-Zagłębiowskiej Metropolii „Silesia”, [w:] I. Jażewicz (red.), Wspótczesne problemy przemian strukturalnych przestrzeni geograficznej, Wydawnictwo Naukowe Akademii Pomorskiej, Słupsk, s. 496-511. 
Zborowski A., 2005, Przemiany struktury społeczno-przestrzennej regionu miejskiego w okresie realnego socjalizmu i transformacji ustrojowej (na przyktadzie Krakowa), Instytut Geografii i Gospodarki Przestrzennej UJ, Kraków.

[Wpłynęło: marzec; poprawiono: sierpień 2012 r.]

\title{
KRZYSZTOF GWOSDZ, AGNIESZKA SOBALA-GWOSDZ
}

\author{
FUNCTIONAL STRUCTURE AND LINKAGES \\ BETWEEN THE TOWNS AND CITIES OF THE KATOWICE CONURBATION \\ AFTER TWO DECADES OF POST-SOCIALIST TRANSITION
}

This paper seeks to analyse the contemporary functional and spatial structure of Poland's Katowice conurbation - a unique settlement form in Poland that developed initially as the result of 19th and 20th century industrialisation processes based around primary energy obtained from deposits of hard coal. In particular, the work described here revolves around the following research questions:

1. What is the functional structure and hierarchy of towns and cities in the Katowice conurbation two decades into the restructuring process (1989-2009)?

2. In what direction have linkages between particular towns and cities of the Katowice conurbation developed (on the basis of commuters flows in 2006)?

3. How may the regularities and tendencies observed with respect to the Katowice conurbation be understood and explained in the context of theoretical frameworks pertaining to the development of urban systems?

These questions were addressed with the aid of a research procedure that first entailed the use of comprehensive data on employment (after NACE rev. 1.1.) to calculate the size and level of diversification of the economic base of each of the conurbation's cities. The position of the towns and cities with respect to central functions was then delimited by reference to a scalar synthetic indicator and the size of the exogenous sector with respect to services. Linkages between cities were assessed on the basis of volumes and directions of commutes to work in 2006.

By reference to the historic agglomeration types proposed by N. Phelps and T. Ozawa (2003), it was concluded that the present-day organisational features of the Katowice conurbation make it more akin to the late-industrial model described by A. Scott (1982) than to the post-industrial model of P. Hall (1997). This is manifested in the still-large (45\%) share of the conurbation's economic base that is accounted for by industrial activities, as accompanied by a strong division of labour between the service core of the agglomeration - wherein the role of city is played by Katowice - and other urban centres of a mainly industrial (or industrial-service) character that serve as the agglomeration's nodes.

Secondly, unlike in the post-industrial agglomeration model, the past two decades have witnessed a strengthening of the service core of the agglomeration (Katowice), without any signs of selective deconcentration of service activities to edge zones. The late-industrial character of the Katowice conurbation is further confirmed by the trends noted for the development of its economic base in the first decade of the 21st century. 
Medium-high technology manufacturing industries (mainly automotive) were the main growing exogenous activity in the conurbation, followed by business services, the latter being mainly the effect of multiplier effects generated by industrial producers.

The two main processes seen to influence the conurbation's functional and spatial organization are the growing concentration of higher-rank functions in Katowice, leading to strong hierarchical linkages within the entire urban region; as well as the (converse) perpetuation of the polycentric character of the analysed urban form in line with the distribution of the still-very-important industrial function and population. It is most likely that this trend will be maintained in the coming decade, there being no premises upon which to envisage the deconcentration of service functions. At the same time, processes of reindustrialization continue, mainly as greenfields (Gliwice and Tychy), but also as brownfields in selected cities of the conurbation core (Sosnowiec and Siemianowice Śląskie). A second visible process pertains to the increased importance of the conurbation's southern and external zone. With respect to this, emphasis should be placed on the organizing, economic and spatial role of the main transport corridors, especially the A4 motorway. 
http://rcin.org.pl 